\title{
Single versus Multiple-doses of Methotrexate: A Retrospective Cohort Study to Compare the Efficacy and Observed Side Effects in Management of Ectopic Pregnancies
}

\author{
Tekli ve Çoklu Doz Metotreksat Dozları: Ektopik Gebeliklerin Tedavisinde Etkinliği ve Gözlenen Yan Etkileri \\ Karşılaştırmak için Retrospektif Bir Kohort Çalışması
}

\section{Zeinab Nazari ${ }^{1}$, Hamed Jafarpour ${ }^{2}$, Mohammad Tabarestani ${ }^{2}$, Sara Sadr ${ }^{2}$, Ahmadreza Shafizadeh ${ }^{3}$, Fatemeh Shafizadeh ${ }^{1}$}

${ }^{1}$ Mazandaran University of Medical Sciences, Sari, Iran

${ }^{2}$ Student Research Committee, Faculty of Medicine, Mazandaran University of Medical Science, Sari, Iran

${ }^{3}$ Student Research Committee, Faculty of Medicine, Golestan University of Medical Science, Golestan, Iran

\section{ABSTRACT}

Aim: In this study we aimed to compare the efficacy and observed side effects of the two used Methotrexate administration protocols in treatment of ectopic pregnancies.

Methods: In this retrospective cohort study, 83 patients that met the inclusion criteria and were previously assigned to either the single-dose methotrexate regimen protocol (a single $50 \mathrm{mg} / \mathrm{m}^{2}$ intramuscular MTX injection) or the multiple-dose methotrexate protocol $\left(1 \mathrm{mg} / \mathrm{kg}\right.$ on the $1^{\text {st }}, 3^{\text {rd }}, 5^{\text {th }}$ and $7^{\text {th }}$ day of the treatment). Side effects and alterations in the human chorionic gonadotropin $(\beta-H C G)$ levels on the $1^{\text {st }}, 4^{\text {th }}$ and $7^{\text {th }}$ day after initiation of treatment were obtaines from patient case files.

Results: Eighty three out of 98 patients that were treated with MTX met all the inclusion criteria. The average age of patients was 30.17 years, the mean gravida was 1.9 and the mean EP diameter was $36.63 \mathrm{~mm}$. The hospitalization duration was shorter in the multiple-dose regimen group ( 3.85 days compared to 4.53 days). The endometrial thickness was higher in patients undergoing multiple-dose treatment ( $11.75 \mathrm{~mm}$ compared to 8.75 ). The prevalence of anemia, thrombocytopenia, leukopenia, raised liver enzymes and pain were not significantly different between the two groups $(p>0.05)$. The treatment success rates were $78 \%$ and $85 \%$ for the single-dose regimen and the multipledose regimen, respectively ( $p>0.05$ ). There was one reported case of fallopian tube rupture in the single-dose regimen group and two in the multiple-dose regimen group ( $p>0.05)$.

Conclusion: Treatment success rates, the prevalence of side effects (Gastroenteritis, leukopenia, anemia, thrombocytopenia, bone marrow suppression) and alterations in $\beta$-HCG levels were not significantly different between the two treatment groups. We concluded that with fewer adverse effects and the same therapeutic benefits, a single-dose methotrexate regimen is preferable in a case of an unruptured EP with stable hemodynamics.

Key Words: Ectopic pregnancy, methotrexate, single-dose protocol, multipledose protocol

Received: 06.26 .2018
Accepted: 08.14.2018
ÖZET

Amaç: $\mathrm{Bu}$ çalışmada, ektopik gebeliklerin tedavisinde kullanılan iki metotreksat uygulama protokolünün etkinliği ve gözlenen yan etkilerini karşılaştırmayı amaçladık.

Yöntemler: Bu retrospektif kohort çalışmasında, dahil etme kriterlerini karşılayan ve daha önce tek doz metotreksat rejimi protokolüne (tek bir $50 \mathrm{mg}$ / m2 intramüsküler MTX enjeksiyonu) veya çok doz metotreksat protokolüne (1 mg / kg tedavinin 1., 3., 5. ve 7. günü) dahil edildi. Tedavinin başlamasından sonraki 1., 4. ve 7. günlerde insan koryonik gonadotropin ( $\beta$-HCG) düzeylerindeki yan etkiler ve değişiklikler hasta olgu dosyalarından elde edildi. Bulgular: MTX ile tedavi edilen 98 hastanın 83 'ü tüm dahil etme kriterlerini karşıladı. Hastaların ortalama yaşı 30.17 , ortalama gravidası 1.9 ve ortalama EP çapı $36.63 \mathrm{~mm}$ idi. Hastanede kalış süresi çok dozlu rejim grubunda daha kısaydı (4.53 güne kıyasla 3.85 gün). Çoklu doz tedavisi alan hastalarda endometrial kalınlık daha yüksekti $(8,75$ 'e göre $11,75 \mathrm{~mm})$. Anemi, trombositopeni, lökopeni, yüksek karaciğer enzimleri ve ağrı prevalansı iki grup arasında anlamlı farklılık göstermedi ( $p>0.05)$. Tedavi başarı oranları, tek doz rejimi ve çoklu doz rejimi için sırasıyla\% 78 ve \% 85 idi ( $p>0.05$ ). Tek doz rejimi grubunda bir tane fallop tüp rüptürü vakası ve çoklu doz rejimi grubunda iki tane bildirildi ( $p>0.05$ ).

Sonuç: Tedavi başarı oranları, yan etkilerin prevalansı (Gastroenterit, lökopeni, anemi, trombositopeni, kemik iliği baskılanması) ve $\beta$-HCG düzeyindeki değişiklikler iki tedavi grubu arasında anlamlı farklılık göstermedi. Daha az yan etki ve aynı terapötik faydaların olduğu gibi, stabil hemodinamiğe sahip bozulmamış bir EP durumunda tek doz metotreksat rejiminin tercih edildiği sonucuna vardık.

Anahtar Sözcükler: Ektopik gebelik, metotreksat, tek doz protokolü, çoklu doz protokolü 


\section{INTRODUCTION}

An ectopic pregnancy (EP) is a pregnancy located outside the uterus. The fallopian tubes that connect the ovaries to the uterus are the most common location for an EP (1). Despite the advances made in the field, EPs are still an important cause of death among women in their reproductive age. The most often taken course of action remains to be invasive surgery even though medical therapy has been extensively researched and studies (2). A review of controlled and uncontrolled trials shows that medical therapy is just as effective as surgery in a stable patient (3-5). Medical therapy for tubal pregnancies is of special interest because medical therapy causes less injury to the fallopian tubes, costs less, there is a better chance of future pregnancies and it eliminates risks associated with surgery and anesthesia. Methotrexate, a folic acid antagonist is used to extirpate the trophoblast in an EP (1). In 1982, Tanaka et al used MTX as medical therapy for EP for the first time. Previous longitudinal studies have not shown an increase in the risk of congenital anomalies, spontaneous abortion, and tumors after chemotherapy with MTX (6). Different resources imply that a multiple-dose protocol is preferable to a single-dose protocol, but in recent studies, the single-dose protocol has been considered more efficient due to fewer side effects (7).

Considering MTX is a folic acid antagonist chemotherapeutic agent, numerous side effects are expected (1). Leukopenia, Thrombocytopenia, Stomatitis, dermatitis and bone marrow aplasia are some of the more important expected side effects. Although, these side effects are quite rare when MTX is taken in small doses as in EP protocols; specially if folic acid supplements are added to the regimen, no serious side effects are expected (5). MTX can be administered by Intermuscular injections in single or multipledoses, or by transvaginal ultrasound-guided inter-tubular injections or even orally to treat EP. In recent years, Intermuscular MTX injection has become the quite popular since it is easily administered, less invasive cheaper and has been associated with fewer side effects. Using MTX as a treatment for EP remains a controversial subject in the literature. Medical treatment can only be offered to patients that fully meet the protocol criteria and the medical facilities that offer this treatment must have the equipment to follow up the treatment. The therapeutic dose of MTX in the single-dose protocol is 50 $\mathrm{mg} / \mathrm{m}^{2}$ which is about 75 to 90 milligrams for most patients. $(3,5-8)$.

Considering the controversial results of similar studies regarding the efficacy, side effects, need for hospitalization and expense of this medical therapy, in this retrospective cohort study we aimed to compare the efficacy and observed side effects of the two used Methotrexate administration protocols (single-dose versus multiple-doses) in treatment of ectopic pregnancies in patients that were treated in the Imam Khomeini and Shafa Hospitals, Sari, Iran during a one year period (May 2016 to May 2017).

\section{METHODS}

This retrospective cohort study was done on 83 patients that had been diagnosed with ectopic pregnancies and had been treated with MTX, in the Imam Khomeini and Shafa hospitals, Sari, Iran from May 2016 to May 2017. Patients' treatment data were collected using the patient files and the hospital medical records. The design of this study was approved by the Ethics Committee of Mazandaran University of Medical Sciences, Mazandaran, Iran (IR.MAZUMS.IMAMHOSPITAL.REC.96.2844)

Diagnosis of an ectopic pregnancy was made based on laboratory and imaging (transvaginal sonography) techniques. Patients who weren't initially unstable and in need of immediate surgical intervention and patients who were otherwise immunocompromised had been treated surgically and did not enter our study. All patients with a positive $\beta$-HCG test were followed until an intrauterine pregnancy or an ectopic pregnancy was confirmed, in which case the patient was considered to participate in the study. The diagnosis of an EP was confirmed in patients with a $\beta$-HCG level higher or equal to $1800 \mathrm{mIU} / \mathrm{mL}$, with no evidence of intrauterine pregnancy in ultrasonography. For patients suspected of EP who had a $\beta$-HCG level lower than 1800 further investigation using the Stovall \& Ling algorithm was done.

Table 1: Comparison of mean age and gestational age between the two treatment groups

\begin{tabular}{|c|c|c|c|c|c|c|}
\hline & Treatment Group & count & Mean & $\begin{array}{l}\text { Standard } \\
\text { Deviation }\end{array}$ & Probability & $95 \% \mathrm{Cl}$ \\
\hline \multirow[t]{2}{*}{ Age } & Single-dose treatment & 41 & 30.85 & 5.14 & \multirow{2}{*}{.611} & \multirow[t]{2}{*}{$(-1.81,3.06)$} \\
\hline & Multiple-dose treatment & 42 & 30.23 & 5.79 & & \\
\hline \multirow[t]{2}{*}{ Gestational age } & Single-dose treatment & 41 & 6.23 & 1.66 & \multirow{2}{*}{.450} & \multirow{2}{*}{$(1.00, .45)$} \\
\hline & Multiple-dose treatment & 42 & 6.50 & 1.59 & & \\
\hline
\end{tabular}

The inclusion criteria were as follows: No sign of bleeding in transvaginal ultrasonography, stable hemodynamic status, a tubal diameter of 4 centimeters or less, $\beta$-HCG levels of $15000 \mathrm{mIU} / \mathrm{mL}$ or less, an absence of a fetal heart rate and an incentive for future pregnancies.

The exclusion criteria were as follows: Immune deficiency, moderate or severe anemia, leukopenia, thrombocytopenia, peptic ulcer disease, elevated liver enzymes, hepatic adenoma, kidney failure, hemodynamic instability, pelvic tenderness, positive fetal heart rate, gross rectorrhagia and signs of a ruptured tube. The follow-up laboratory studies were done out-patient along with visits to the hospital's day clinic. Expected MTX adverse effects including gastroenteritis, bone marrow suppression, and elevated liver enzymes were also checked.

For patients in the group that were treated with a single-dose protocol, 50 $\mathrm{mg} / \mathrm{m}^{2}$ intramuscular methotrexate was administered on the $1^{\text {st }}$ day and $\beta$ HCG levels were measured on the $4^{\text {th }}$ and the $7^{\text {th }}$ day of treatment. If the $\beta$ HCG levels did not decrease by $15 \%$ between the $4^{\text {th }}$ and the $7^{\text {th }}$ day of treatment, a second dose of methotrexate was administered. If the decrease of $\beta$-HCG was significant ( $15 \%$ or more), a weekly measurement of $\beta$-HCG was done until normal levels (less than $15 \mathrm{mIU} / \mathrm{mL}$ ) were achieved. For patients in the group that were treated with a multiple-dose regimen, $1 \mathrm{mg} / \mathrm{kg}$ methotrexate was administered on the $1^{\text {st }}, 3^{\text {rd }}, 5^{\text {th }}$ and $7^{\text {th }}$ days of treatment; and $0.1 \mathrm{mg} / \mathrm{kg}$ of folinic acid (citrovorum factor) was administered on the $2^{\text {nd }}$, $4^{\text {th }}, 6^{\text {th }}$ and the $8^{\text {th }}$ day of treatment. A success rate was defined by the percentage of patients that showed significant decrease in their $\beta$-HCG levels in each group. A minimum of $15 \%$ decrease in $\beta$-HCG levels on the $7^{\text {th }}$ day of treatment along with a $\beta$-HCG level less than $15 \mathrm{mlU} / \mathrm{mL}$ after 6 weeks of treatment, was considered a significant in the single-dose group. And in the multiple-dose group, a minimum of $15 \%$ decrease in $\beta$-HCG levels by 48 hours after initiation of treatment or after 4 doses of methotrexate along with a $\beta$ HCG level less than $15 \mathrm{mlU} / \mathrm{mL}$ after 6 weeks of treatment. A questionnaire was used to collect patient's demographic information such as age, gravidity, parity and gestational age, also laboratory studies such as $\beta-H C G$, hemoglobin, WBC, Platelet count and imaging results including endometrial line and the EP diameter were also documented. Expected side effects such as gastroenteritis, bone marrow suppression and an increase in liver function tests and follow up $\beta$-HCG levels were also documented in the questionnaire.

Mean and standard deviation were calculated for quantitative variables such as age and, qualitative variables such as response to treatment were summarized and reported using distribution charts. Statistical analysis of background variables and confounding variables were done using chi-square and independent t-test to compare the two treatment groups. Response to treatment was also analyzed using chi-square testing and in case of a confounding variable, logistic regression was also performed. A p-value less than 0.05 was considered statistically significant for all analyzed material. IBM SPSS Statistics 23 software was used for all the statistical analysis.

\section{RESULTS}

Patients: 98 patients were found eligible to enter the study; 12 patients had not complied with the follow-up laboratory studies and had insufficient data and 3 patients were excluded based on their primary laboratory studies. Information regarding 83 patients were analyzed of which 41 and 42 patients were treated with a single-dose and a multiple-dose regimen, respectively.

Also, for the examination of the hypothesis of the normality of data distribution, Kolmogorov-Smirnov test was used which showed a normal distribution for all variables except for $\beta$-HCG levels on the $1^{\text {st }}, 4^{\text {th }}$ and $7^{\text {th }}$ day of treatment consequently, parametric and non-parametric analysis was done.

The mean age of the single and multiple-dose treatment groups were 30.85 years and 30.23 years, respectively. The mean gestational age of patients assigned to the single-dose regimen and multiple-dose regimen were 6.23 weeks and 6.5 weeks, respectively. $51.2 \%$ of patients that were treated with a single-dose regimen were gravida $1,41.5 \%$ were gravida 2 and $7.3 \%$ were gravida 3 or more. Among patients treated with the multiple-dose regimen, $45.3 \%$ were gravida $1,40.55 \%$ were gravida 2 and $14.2 \%$ were gravida 3 or more. There was no statistically significant difference between the two groups regarding age, gestational age and gravidity (Table 1, 2). 
Table 2: Distribution of gravidity in each treatment group

\begin{tabular}{rrrrrr}
\hline & \multicolumn{2}{c}{ Single-dose treatment } & \multicolumn{2}{c}{ Multiple-dose treatment } & \multirow{2}{*}{ Probability } \\
& $\mathrm{N}$. & $\%$ & $\mathrm{~N}$. & $\%$ & \\
\hline 1 & 21 & $51.2 \%$ & 19 & $45.3 \%$ & \\
2 & 17 & $41.5 \%$ & 17 & $40.5 \%$ & $890 / 0$ \\
3 and more & 3 & $7.3 \%$ & 6 & $14.2 \%$ & \\
Total & 41 & $100.0 \%$ & 42 & $100.0 \%$ & \\
\hline
\end{tabular}

Gastroenteritis as an adverse effect of the treatment was reported in $19.4 \%$ of patients in the single-dose treatment group and $19 \%$ of patients in the multiple-dose group; this difference was not statistically significant(Table 3).

Table 3: Prevalence of gastroenteritis in two treatment groups

\begin{tabular}{rrrrrr}
\hline \multirow{2}{*}{ Pain } & \multicolumn{2}{c}{ Single-dose treatment } & \multicolumn{2}{c}{ Multiple-dose treatment } & Probability \\
& $\mathrm{N}$. & $\%$ & $\mathrm{~N}$. & $81.0 \%$ & \multirow{2}{*}{592} \\
\hline not reported & 31 & $75.6 \%$ & 34 & $19.0 \%$ & .592 \\
reported & 10 & $19.4 \%$ & 8 & $100.0 \%$ & \\
Total & 41 & $100.0 \%$ & 42 & & \\
\hline
\end{tabular}

The initial mean hemoglobin levels of the patients treated with the singledose treatment was $11.29 \mathrm{~g} / \mathrm{dL}$ and was $10.66 \mathrm{~g} / \mathrm{dL}$ after the treatment course. The mean hemoglobin levels of the patients treated with the multipledose regimen was $11.26 \mathrm{~g} / \mathrm{dL}$ before administration of MTX and $10.63 \mathrm{~g} / \mathrm{dL}$ after completion of the treatment course. Even though the decrease in hemoglobin levels were significant in both groups, there was no statistically significant difference between the extent to which the hemoglobulin levels were decreased in each group.
The initial mean white cell counts in the single and multiple-dose groups were $7,755^{*} 10^{9} / \mathrm{L}$ and $7,910 * 10^{9} / \mathrm{L}$ respectively and each decreased to $7,343 * 10^{9} / \mathrm{L}$ and $7,328 * 10^{9} / \mathrm{L}$ after administration of MTX. The decrease in WBC was significant in each group but the decrease in WBC count was not significantly more than the other in either group.

The mean of the initial platelet counts in the single-dose group was $271.8 * 10^{9} / \mathrm{mcL}$ and it decreased to $254.55^{*} 10^{9} / \mathrm{mcL}$ after treatment; and the mean of the initial platelet count in the multiple-dose regimen group dropped from $273.6^{*} 10^{9} / \mathrm{mcL}$ to $257.35^{*} 10^{9} / \mathrm{mcL}$ after treatment. The decrease in the mean value of platelet levels were not significant in each group or in the comparison between the two groups (Table 4).

Table 4: Comparing the mean HB, HCT, PLT and WBC levels in both treatment groups be

\begin{tabular}{|c|c|c|c|c|c|c|c|}
\hline & \multirow[t]{2}{*}{ Treatment Group } & \multicolumn{2}{|c|}{ Initial (before treatment) } & \multicolumn{2}{|c|}{ Post-treatment } & \multirow[t]{2}{*}{ Probability } & \multirow[t]{2}{*}{$\mathrm{Cl} \% 95$} \\
\hline & & Mean & $\begin{array}{l}\text { Standard } \\
\text { Deviation }\end{array}$ & Mean & $\begin{array}{l}\text { Standard } \\
\text { Deviation }\end{array}$ & & \\
\hline \multirow[t]{4}{*}{ HG } & Single-dose treatment & 11.29 & .88 & 10.66 & .65 & .000 & $(.37, .91)$ \\
\hline & $\begin{array}{c}\text { Multiple-dose } \\
\text { treatment }\end{array}$ & 11.26 & .89 & 10.63 & .64 & .000 & \multirow[t]{3}{*}{$(.37, .90)$} \\
\hline & Probability & & .880 & & .863 & & \\
\hline & $95 \% \mathrm{Cl}$ & $(-.36, .42)$ & & $(-.26, .31)$ & & & \\
\hline \multirow[t]{4}{*}{ WBC } & Single-dose treatment & 7755.00 & 1251.04 & 7343.25 & 921.32 & .015 & \multirow{3}{*}{$\begin{array}{l}(85.39,738.11) \\
(156.63,1006.37 \\
)\end{array}$} \\
\hline & $\begin{array}{c}\text { Multiple-dose } \\
\text { treatment }\end{array}$ & 7910.00 & 1322.93 & 7328.50 & 921.57 & .009 & \\
\hline & Probability & & .592 & & 943. & & \\
\hline & $95 \% \mathrm{Cl}$ & $(-728.15,418.15)$ & & $(-395.45,424.95)$ & & & \\
\hline \multirow[t]{4}{*}{ PLT } & Single-dose treatment & 271.80 & 51.10 & 254.55 & 69.04 & .087 & \multirow{3}{*}{$\begin{array}{l}(-2.62,37.12) \\
(-3.26,35.76)\end{array}$} \\
\hline & $\begin{array}{c}\text { Multiple-dose } \\
\text { treatment }\end{array}$ & 273.60 & 52.18 & 257.35 & 67.48 & .100 & \\
\hline & Probability & & .877 & & .855 & & \\
\hline & $95 \% \mathrm{Cl}$ & $(-24.79,21.19)$ & & $(-33.19,27.59)$ & & & \\
\hline \multirow[t]{4}{*}{$\mathrm{HCT}$} & Single-dose treatment & 35.07 & 2.42 & 34.01 & 2.29 & .010 & \multirow{4}{*}{$\begin{array}{l}(.27,1.85) \\
(-.18,1.43)\end{array}$} \\
\hline & $\begin{array}{c}\text { Multiple-dose } \\
\text { treatment }\end{array}$ & 34.79 & 2.65 & 34.17 & 1.93 & .122 & \\
\hline & Probability & & .636 & & .737 & & \\
\hline & $95 \% \mathrm{Cl}$ & $(-.86,1.40)$ & & $(-1.10, .78)$ & & & \\
\hline
\end{tabular}

The mean AST, ALT and ALP levels in the group treated with the single-dose regimen were respectively $23.27,13.35$ and $135.13 \mathrm{U} / \mathrm{L}$; and in the multipledose regimen group the mean values were $26.05,13.3$ and $136.2 \mathrm{U} / \mathrm{L}$ in the same order. The liver enzyme levels showed no significant difference between the two treatment groups (Table 5). 
Table 5: Comparison of mean ALP, AST amd ALT levels in the two treatment groups

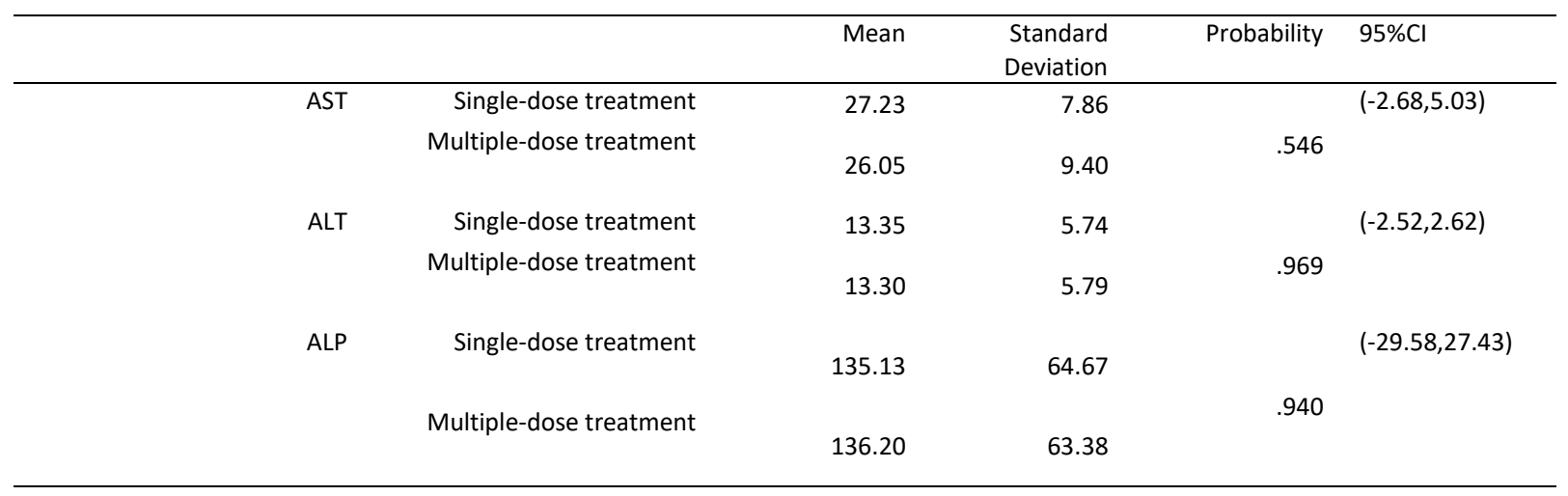

The mean of the initial HCT percentages in patients assigned to the singledose regimen was $35.07 \%$ which decreased to $34.79 \%$ after treatment with MTX; this drop in HCT percentages was significant. In patients treated according to the multiple-dose protocol, the mean HCT percentage increased from 34.01 to 34.17 which was not statistically significant, nor was the difference between the extent to which the HCT percentage changed in either group(Table 4).
The mean duration of hospitalization was 4.35 days for the single-dose regimen group and 3.85 days for the multiple-dose regimen group. The size of the EP diameter was 34.7 and $34.58 \mathrm{~mm}$ for single and multiple-dose regimen groups respectively. There was no significant difference between the mean duration of stay or the mean size of the EP between the two groups. The mean endometrial in groups treated with the single and multiple-dose regimens were 8.75 and $11.75 \mathrm{~mm}$ respectively; which was a statistically significant difference (Table 6).

Table 6: Comparing the mean EP diameter, Hospitalization duration and endometrial thickness in the two treatment groups

\begin{tabular}{|c|c|c|c|c|c|}
\hline & & Mean & $\begin{array}{l}\text { Standard } \\
\text { Deviation }\end{array}$ & Probability & $95 \% \mathrm{Cl}$ \\
\hline EP diameter & Single-dose treatment & 34.70 & 13.38 & .967 & $(-5.81,6.01)$ \\
\hline & Multiple-dose treatment & 34.58 & 13.26 & & \\
\hline \multirow[t]{3}{*}{ Hospitalization duration } & Single-dose treatment & 4.53 & 1.63 & & $(-.01,1.36)$ \\
\hline & Multiple-dose treatment & & & .055 & \\
\hline & & 7.85 & 1.46 & & \\
\hline \multirow[t]{2}{*}{ Endometrial thickness } & Single-dose treatment & 8.75 & 4.28 & .007 & $(-.520,-.85)$ \\
\hline & Multiple-dose treatment & 11.75 & 5.42 & & \\
\hline
\end{tabular}

The mean $\beta$-HCG level in the single-dose regimen group was 1803.13 $\mathrm{mIU} / \mathrm{mL}$ before initiation of treatment which decreased to $1212.04 \mathrm{mIU} / \mathrm{mL}$ four days after administration of MTX; and it continued to decrease to 908.83 on the $7^{\text {th }}$ day of treatment. The mean $\beta$-HCG levels of the patients treated with multiple-doses of MTX were initially $1811.61,1221.55$ on the $4^{\text {th }}$ day of treatment and 798.61 on the $7^{\text {th }}$ day of treatment.
There was no significant difference between two groups before and after treatment although $\beta$-HCG levels dropped considerably in each group afte treatment. The difference between how much each regimen was effective in lowering the $\beta$-HCG levels showed no statistically significant difference (Table 7).

Table 7: Comparing the mean $\beta$-HCG levels in the two treatment groups before and after treatment

\begin{tabular}{|c|c|c|c|c|c|c|c|}
\hline \multirow[t]{2}{*}{ Treatment Group } & \multicolumn{2}{|c|}{ Initial (before treatment) } & \multicolumn{2}{|c|}{ The $4^{\text {th }}$ day of treatment } & \multicolumn{2}{|c|}{ The $7^{\text {th }}$ day of treatment } & \multirow[t]{2}{*}{ Probability } \\
\hline & Mean & $\begin{array}{l}\text { Standard } \\
\text { Deviation }\end{array}$ & Mean & $\begin{array}{l}\text { Standard } \\
\text { Deviation }\end{array}$ & & & \\
\hline $\begin{array}{c}\text { Single-dose } \\
\text { treatment }\end{array}$ & 1803.13 & 1650.13 & 1212.04 & 703.07 & 908.83 & 432.64 & .000 \\
\hline $\begin{array}{c}\text { Multiple-dose } \\
\text { treatment }\end{array}$ & 1811.61 & 1647.41 & 1221.55 & 698.99 & 798.61 & 220.16 & .000 \\
\hline Probability & & .985 & & .946 & & .303 & \\
\hline
\end{tabular}

The overall treatment success was $78 \%$ in the single-dose regimen group and $85 \%$ in the multiple-dose regimen group and treatment failure was respectively $22 \%$ and $15 \%$ which showed no statistically significant difference between the two groups ( $p>0.05)$

Table 8: Comparison of treatment failure in the two treatment groups

\begin{tabular}{|c|c|c|c|}
\hline Treatment Group & Single-dose & $\begin{array}{r}\text { Multiple-dose } \\
\text { treatment }\end{array}$ & Probability \\
\hline Tubal rupture & 1 & 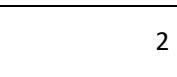 & 0.596 \\
\hline $\begin{array}{r}\text { NO o response to } \\
\text { treatment }\end{array}$ & 21 & 13 & 0.055 \\
\hline
\end{tabular}

Two patients in the multiple-dose regimen group and one patient in the single-dose regimen group were diagnosed with tubular rupture which were therefore considered treatment failures. 21 and 13 patients in the single and multiple-dose regimen groups showed no response to treatment (Table 8). 
There was a correlation between the initial $\beta$-HCG levels and EP diameter size and duration of hospitalization but with a margin of error of 5 percentage points, there was not a statistically significant correlation between patients' $\beta$-HCG levels and the endometrial thickness. (Table 9).
There was a correlation between the duration of hospitalization and the EP diameter size; although the duration of hospitalization did not correlate with endometrial thickness (Table 10).

Table 9: Evaluating the correlation between the initial $\beta$-HCG level and endometrial thickness, EP diameter and duration of treatment

\begin{tabular}{|c|c|c|c|c|}
\hline Treatment Group & & $\begin{array}{r}\text { Endometrial } \\
\text { thickness }\end{array}$ & EP diameter & $\begin{array}{c}\text { Duration of } \\
\text { treatment }\end{array}$ \\
\hline \multirow[t]{2}{*}{ Single-dose } & $\begin{array}{l}\text { Correlation } \\
\text { coefficient }\end{array}$ & .299 & .555 & .383 \\
\hline & Probability & .061 & .000 & .015 \\
\hline \multirow[t]{2}{*}{$\begin{array}{r}\text { Multiple-dose } \\
\text { treatment }\end{array}$} & $\begin{array}{l}\text { Correlation } \\
\text { coefficient }\end{array}$ & .284 & .422 & .571 \\
\hline & Probability & .075 & .007 & .000 \\
\hline
\end{tabular}

Table 10: Evaluating the correlation between duration of treatment and EP diameter and Endometrial thickness

\begin{tabular}{|c|c|c|c|}
\hline Treatment Group & & $\begin{array}{r}\text { Endometrial } \\
\text { thickness }\end{array}$ & EP diameter \\
\hline \multirow[t]{2}{*}{ Single-dose } & $\begin{array}{l}\text { Correlation } \\
\text { coefficient }\end{array}$ & .029 & .632 \\
\hline & Probability & .859 & .000 \\
\hline \multirow[t]{2}{*}{$\begin{array}{r}\text { Multiple-dose } \\
\text { treatment }\end{array}$} & $\begin{array}{l}\text { Correlation } \\
\text { coefficient }\end{array}$ & .082 & .304 \\
\hline & Probability & .617 & .056 \\
\hline
\end{tabular}

\section{DISCUSSION}

Out of 98 patients diagnosed with EP patients that entered the study, the data regarding the treatment of 83 patients that had been treated with MTX was collected and analyzed. 41 out of 83 patients were treated with a single dose regimen of MTX and the remaining 42 were treated according to the multiple dose regimen. Age, gravidity, parity, and possible risk factors of ectopic pregnancy were factors of significant difference between the two groups of treatment.

The treatment success rate in the single-dose group was $78 \%$ and $85 \%$ for the multiple-dose regimen group. Three studies done by Hamed, Saadati, and Song that included 325 patients with a diagnosis of an un-ruptured EP and stable hemodynamic, showed a slightly higher efficacy rate with the multipledose regimen (9-11). In clinical trials done by Alleyasin, Guvendag, and Bafghi on 298 patients, the results did not show a considerable difference between the efficacy rate of a multiple-dose against a single-dose regimen (12-14). In a study done by Saraj, the success rate of a single-dose MTX treatment was calculated $94.7 \%(15)$. In a similar study success rate of a single-dose MTX therapy was reported $83.7 \%$ (16). In another comparative study, Kim et al reported a $64.2 \%$ and $71.9 \%$ success rate for the single and multiple-dose regimen respectively; although this difference was not statistically significant (17). In a study done by Elkilani et al, efficacy of multiple and single-dose MTX therapy was studied on 50 patients, which showed a success rate of $90 \%$ for patients treated with a single-dose of MTX, and $95 \%$ for patients with multiple-doses of MTX which was a statistically significant difference (7). In another similar study, the success rate of a single-dose MTX therapy was $88.9 \%$ compared to a $92.6 \%$ success rate of a multiple-dose regimen (13). In a study done in the city of Yazd, in the year 2000, among 72 patients diagnosed with ectopic pregnancy, four patients received medical therapy which was successful for only one patient (18).

In a study done by Barnhart the overall success rate of treatment with a single-dose MTX was $88.1 \%$ (940 patients out of 1067) and with a confidence interval of $95 \%$ the success rate would be calculated $86 \%$ to $90 \%$; and the overall success rate of treatment with a multiple-dose regimen of MTX was $92 \%$ (24 out of 260 patient) which with a confidence interval of $95 \%$ would be calculated $89 \%$ to $96 \%$. The difference between the success rates of multiple and single-dose regimens of MTX was statistically significant $(P=0.035)$ the writers also clarified that their study design was not blind and a randomized blind study needs to be done in order to minimize the interfering bias (5). In a study done by Song et. Al. the success rate of a double dose treatment was significantly more in patients with a $\beta$-HCG level higher than $5000 \mathrm{U} / \mathrm{L}(10)$. In another study, the success rate of treatment was more in patients with an initial $\beta$-HCG level between 3000 and $5500 \mathrm{U} / \mathrm{L}$; also patients with an EP size between 2.7 and $3.5 \mathrm{~cm}$ showed the highest response rate to treatment (9). Based on our laboratory data, the $\beta$-HCG decrease in response to treatment was $74.39 \%$ in the single-dose treatment group and $83 \%$ in the multiple-dose regimen group. In a study, done by Morlock et al, the $\beta$-HCG decrease in the single-dose treatment group was $87 \%$ (19).
In this study, the response rate was $74.39 \%$ in the single-dose group and $83 \%$ in the multiple-dose regimen group. In our study, there was a reverse correlation between endometrial thickness and response to treatment; which was compatible with Elikani's study result (7).

In our study, the incidence of perceived side effects in the multiple and single-dose regimen treatment groups were not significantly different; although gastroenteritis and a decrease in hemoglobulin level were observed more in the multiple-dose regimen group, this difference was not statistically significant. In three randomized clinical trial studies done by Hamed, Saadati and Song that compared the effects of single and multiple-dose MTX treatment in management of EP on 325 patients, no statistically significant difference was shown (9-11); although in the study done by Alleyasin, Guven and Bafghi the incidence rate of side effects were significantly higher in patients treated with multiple-doses of MTX(12-14). In another study done in the University of Pennsylvania, mild and temporary side effects were seen In patients treated with a double dose of MTX.(20) In a study done in Ahvaaz side effects were seen more in patients treated with a single-dose of MTX and treatment response was more in patients that also experienced the side effects (21).

Roussos et. al. considered a higher gravidity and absence of a history of prior EPs as positive prognostic factors of tubal rupture (22). Lipnew et. al. published a study in 1999 and reported that the initial $\beta$-HCG level is the best prognostic factor for treatment success rate of a single-dose therapy with MTX in patients with ectopic pregnancies. Information on a family history of PID was not taken into account due to recall bias (23).

Based on the imaging documents, ultrasonography results showed an adnexal mass in $87 \%$ of patients; although there was not a significant size difference between the two groups.

In a study done by Gamzu et. al. they reported that an adnexal mass was seen in $80 \%$ of their patients ( 56 women with EP) that had a size of $4+0.5 \mathrm{~cm}^{2}$, but they also showed that the initial size had no predictive value in their response treatment or $\beta-H C G(24)$. Lipscomb and Mirbolouk, in two different studies, came to the conclusion that the success of treatment and size of the mass are not correlated $(25,26)$. The mean endometrial thickness was not different between the two groups. In a study done by Lim et al on 157 patients, they reported that a tubal pregnancy in a background of a heterogeneous endometer or a pseudosac is associated with a higher chance of treatment failure compared to a homogenous and trilaminar endometer; but the endometrial thickness was not significantly different between the two groups (27). Lipscomb et al reported that the initial $\beta$-HCG level is the most important predicting factor for treatment failure in patients treated with a single-dose MTX. The mean $\beta$-HCG level among patients who had a successful treatment was $4019 \mathrm{U} / \mathrm{L}$, against $13420 \mathrm{U} / \mathrm{L}$ which is the mean $\beta$-HCG level of patients whose treatment failed (25). Mol et at reported that the treatment protocol of choice in patients with a $\beta$-HCG level under $1500 \mathrm{U} / \mathrm{L}$ is a single-dose treatment regimen; and in patients with a $\beta$-HCG level under $3000 \mathrm{U} / \mathrm{L}$ (and over $1500 \mathrm{U} / \mathrm{I}$ ), a multiple-dose regimen in preferable (28). 
In two separate studies done by Gabbur and Erdem, patients were treated with a single-dose regimen of MTX and the decrease in their $\beta$-HCG levels was monitored; though, a drop in $\beta$-HCG level was reported after the treatment, there was no specific "cut off" point for $\beta$-HCG to define treatment success $(29,30)$. Erdem et al reported that among 34 patients whose treatment was considered a failure, 3 patients had a $\beta$-HCG level higher than $4000 \mathrm{U} / \mathrm{L}(26)$. Menon et al reported that based on a study they did on 503 patients, the probability of treatment failure rises as the $\beta$-HCG level passes $5000 \mathrm{U} / \mathrm{L}$; concluding that MTX should be used with care in such patients (31). Based on a study Markwitz did on 68 patients, the probability of treatment failure is high with a $\beta$-HCG level of $1790 \mathrm{U} / \mathrm{L}$ (32). In a study done by Gamzu, the treatment success rate in patients with a $\beta$-HCG level lower than $2000 \mathrm{U} / \mathrm{L}$, was $97 \%$ compared to $74 \%$ success rate in patients with a $\beta$-HCG level higher than $2000 \mathrm{U} / \mathrm{L}$ (33). In a study done by Alleyasin, $34.2 \%$ of patients experienced adverse effects including abdominal pain, diarrhea, and elevated liver enzymes. The incidence rate of adverse effects was $27.8 \%$ among patients treated with a single-dose MTX; and $37 \%$ in patients receiving multiple-doses; this difference was not statistically significant. The most commonly reported side effect was abdominal pain among patients in both groups (13). Elkiani et al reported that the most common and important side effect of treatment with MTX is epigastric abdominal pain; since it was experienced by $60 \%$ of patients in the single-dose group; and 86.7 patients in the multiple-dose group. Other side effects such as hair loss, pelvic pain and oral ulcers were also reported. The only side effects that a different incidence rate between the two groups was vomiting which was more common in patients treated with a multiple-dose regimen. We found that the prevalence of a $15 \%$ or higher drop in $\beta$-HCG levels within the first four days of treatment, was significantly different between patients who received a single or multipledoses of MTX(7). In a study done by Nguyen, $\beta$-HCG dropped by $40 \%$ in the first four days of treatment and was accompanied by a $100 \%$ treatment success rate; although, in $60 \%$ of patients $\beta$-HCG levels increased which then resulted in a $61.8 \%$ treatment success rate; thus, they concluded that the $\beta$ HCG drop in the first four days of treatment has a significant prognostic value regarding treatment response (34). Skubisz also showed that the $\beta$-HCG drop in the first four days of treatment in patients with an initial $\beta$-HCG level lower than $3000 \mathrm{U} / \mathrm{L}$, is a positive predictive value of treatment success $(35,36)$. but in another study, Gabbur showed that only the $\beta$-HCG level on the $7 \mathrm{~h}$ day of treatment has a prognostic value regarding treatment outcome and the $\beta$-HCG level on the $4^{\text {th }}$ day of treatment cannot predict the need for further doses of surgical intervention (29).

If the $\beta$-HCG level on the $4^{\text {th }}$ day of treatment can predict the outcome or probable need for surgical interventions, it would reduce the duration of treatment when it will not be effective; and lead doctors towards surgery without having to postpone an inevitable operation until the $7^{\text {th }}$ day of treatment in a condition that is potentially worrisome for both the doctor and the patient.

In future investigations, a more extensive and longer cohort study would increase the reliability of the results. Long term side effects along with short term side effects of treatment should be evaluated. The treatment expense of either protocol, patient satisfaction rate and the use of a cut-off $\beta$-HCG level for evaluating treatment response should be further investigated. Also subdividing patients based on their initial $\beta$-HCG level in a larger population of cases would increase the reliability of our results and provide us with additional data regarding treatment response in different patients.

\section{CONCLUSION}

In this retrospective cohort study, the treatment success rates, the prevalence of side effects (Gastroenteritis, leukopenia, anemia, thrombocytopenia, bone marrow suppression) and alterations in $\beta$-HCG levels were not significantly different between the two treatment groups. We concluded that with fewer adverse effects and the same therapeutic benefits, a single-dose methotrexate regimen is preferable in a case of an unruptured EP with stable hemodynamics.

\section{Acknowledgement}

This study is part of Dr. Fatemeh Shafi'zadeh's dissertation titled: “Comparing treatment results of single and multiple-dose treatments with MTX in patients with ectopic pregnancies." under the OB/GYN department and was done with financial support from the Mazandaran University of Medical Sciences.

\section{Conflict of interest}

No conflict of interest was declared by the authors.

\section{REFERENCES}

1.Kim HH, Fox JH. The fallopian tube and ectopic pregnancy. Kistner's gynecology and women's health New York: Mosby Inc. 1999:143-65.

2.Kadar N, Caldwell BV, Romero R. A method of screening for ectopic pregnancy and its indications. Obstetrics and gynecology. 1981;58(2):162-6. 3.Nazac A, Gervaise A, Bouyer J, De Tayrac R, Capella-Allouc S, Fernandez H. Predictors of success in methotrexate treatment of women with unruptured tubal pregnancies. Ultrasound in obstetrics \& gynecology. 2003;21(2):181-5.

4.Bai SW, Lee JS, Park JH, Kim JY, Jung KA, Kim SK, et al. Failed methotrexate treatment of cervical pregnancy: predictive factors. Obstetrical \& gynecological survey. 2002;57(10):669-70.

5.Barnhart KT, Gosman G, Ashby R, Sammel M. The medical management of ectopic pregnancy: a meta-analysis comparing "single dose" and "multidose" regimens. Obstetrics \& Gynecology. 2003;101(4):778-84.

6.Tanaka $T$, Hayashi $H$, Kutsuzawa $T$, Fujimoto $S$, Ichinoe $K$. Treatment of interstitial ectopic pregnancy with methotrexate: report of a successful case. Fertility and sterility. 1982;37(6):851-2.

7.Elkilani O, Sayyed T, Metwalli A. Multiple doses versus single-dose methotrexate protocols for the management of some cases of ectopic pregnancy. Menoufia Medical Journal. 2015;28(1):250-3.

8.Sudha V, Thangaraj DR. A retrospective study on ectopic pregnancy: a two year study. International Journal of Reproduction, Contraception, Obstetrics and Gynecology. 2016;5(12):4365-8.

9. Hamed HO, Ahmed SR, Alghasham AA. Comparison of double-and singledose methotrexate protocols for treatment of ectopic pregnancy. International Journal of Gynecology \& Obstetrics. 2012;116(1):67-71.

10.Song T, Kim MK, Kim M-L, Jung YW, Yun BS, Seong SJ. Single-dose versus two-dose administration of methotrexate for the treatment of ectopic pregnancy: a randomized controlled trial. Human Reproduction. 2015:dev312. 11.Saadati N, Najafian M, Masihi S, Safiary S, Abedi P. Comparison of Two Different Protocols of Methotrexate Therapy in Medical Management of Ectopic Pregnancy. Iranian Red Crescent Medical Journal. 2015;17(12).

12.Guvendag Guven ES, Dilbaz S, Dilbaz B, Aykan Yildirim B, Akdag D, Haberal A. Comparison of single and multiple dose methotrexate therapy for unruptured tubal ectopic pregnancy: a prospective randomized study. Acta obstetricia et gynecologica Scandinavica. 2010;89(7):889-95.

13.Alleyassin A, Khademi A, Aghahosseini M, Safdarian L, Badenoosh B, Hamed EA. Comparison of success rates in the medical management of ectopic pregnancy with single-dose and multiple-dose administration of methotrexate: a prospective, randomized clinical trial. Fertility and sterility. 2006;85(6):1661-6.

14.Bafghi AT, Zaretezerjani F, Sekhavat L, Firouzabadi RD, Ramazankhani Z. Fertility Outcome after Treatment of Unruptured Ectopic Pregnancy with Two Different Methotrexate Protocols. International journal of fertility \& sterility. 2012;6(3):189.

15.Saraj AJ, Wilcox JG, Najmabadi S, Stein SM, Johnson MB, Paulson RJ. Resolution of hormonal markers of ectopic gestation: a randomized trial comparing single-dose intramuscular methotrexate with salpingostomy. Obstetrics \& Gynecology. 1998;92(6):989-94.

16.Lecuru F, Robin F, Bernard JP, Maizan de Malartic C, Mac-Cordick C, Boucaya $V$, et al. Single-dose methotrexate for unruptured ectopic pregnancy. International Journal of Gynecology \& Obstetrics. 1998;61(3):253-9.

17.Kim J, Jung YM, Lee DY, Jee BC. Pretreatment serum human chorionic gonadotropin cutoff value for medical treatment success with single-dose and multi-dose regimen of methotrexate in tubal ectopic pregnancy. Obstet Gynecol Sci. 2017;60(1):79-86.

18.Aflatoonian A, Hojat H, Tabibnejad N. Epidemiological Study of Ectopic Pregnancy among Pregnant Women in Yazd, 1999. Journal of Ardabil University of Medical Sciences. 2004;4(4):20-4.

19.Morlock RJ, Lafata JE, Eisenstein D. Cost-effectiveness of single-dose methotrexate compared with laparoscopic treatment of ectopic pregnancy. Obstetrics \& Gynecology. 2000;95(3):407-12.

20.Barnhart K, Hummel AC, Sammel MD, Menon S, Jain J, Chakhtoura N. Use of "2-dose" regimen of methotrexate to treat ectopic pregnancy. Fertility and sterility. 2007;87(2):250-6.

21.Zargar M RT, Barati M. Comparision of Single and Multidose of Methotrexate in Medical Treatment of Ectopic pregnancy. Pak J Med Sci. 2008;24:586-9.

22.Roussos D, Panidis D, Matalliotakis I, Mavromatidis G, Neonaki $M$, Mamopoulos $\mathrm{M}$, et al. Factors that may predispose to rupture of tubal ectopic pregnancy. European Journal of Obstetrics \& Gynecology and Reproductive Biology. 2000;89(1):15-7. 
23.Lipscomb GH, McCord ML, Stovall TG, Huff G, Portera SG, Ling FW. Predictors of success of methotrexate treatment in women with tubal ectopic pregnancies. New England Journal of Medicine. 1999;341(26):1974-8.

24.Gamzu R, Almog B, Levin $Y$, Pauzner $D$, Lessing JB, Jaffa $A$, et al. The ultrasonographic appearance of tubal pregnancy in patients treated with methotrexate. Human reproduction (Oxford, England). 2002;17(10):2585-7.

25.Lipscomb GH, Bran D, McCord ML, Portera JC, Ling FW. Analysis of three hundred fifteen ectopic pregnancies treated with single-dose methotrexate. American journal of obstetrics and gynecology. 1998;178(6):1354-8.

26. Mirbolouk F, Yousefnezhad A, Ghanbari A. Predicting factors of medical treatment success with single dose methotrexate in tubal ectopic pregnancy: a retrospective study. Iranian journal of reproductive medicine. 2015;13(6):351.

27.Choi H-J, Im K-S, Jung H-J, Lim K-T, Mok J-E, Kwon Y-S. Clinical analysis of ovarian pregnancy: a report of 49 cases. European Journal of Obstetrics \& Gynecology and Reproductive Biology. 2011;158(1):87-9.

28. Mol F, Mol B, Ankum W, van der Veen F, Hajenius P. Current evidence on surgery, systemic methotrexate and expectant management in the treatment of tubal ectopic pregnancy: a systematic review and meta-analysis. Human reproduction update. 2008;14(4):309-19.

29.Gabbur N, Sherer DM, Hellmann M, Abdelmalek E, Phillip P, Abulafia O. Do serum beta-human chorionic gonadotropin levels on day 4 following methotrexate treatment of patients with ectopic pregnancy predict successful single-dose therapy? American journal of perinatology. 2006;23(03):193-6.
30.Erdem M, Erdem A, Arslan M, Öç A, Biberoğlu K, Gürsoy R. Single-dose methotrexate for the treatment of unruptured ectopic pregnancy. Archives of gynecology and obstetrics. 2004;270(4):201-4.

31.Menon S, Colins J, Barnhart KT. Establishing a human chorionic gonadotropin cutoff to guide methotrexate treatment of ectopic pregnancy: a systematic review. Fertility and sterility. 2007;87(3):481-4.

32.Nowak-Markwitz E, Michalak M, Olejnik M, Spaczynski M. Cutoff value of human chorionic gonadotropin in relation to the number of methotrexate cycles in the successful treatment of ectopic pregnancy. Fertility and sterility. 2009;92(4):1203-7.

33.Gamzu R, Almog B, Levin Y, Avni A, Jaffa A, Lessing JB, et al. Efficacy of methotrexate treatment in extrauterine pregnancies defined by stable or increasing human chorionic gonadotropin concentrations. Fertility and sterility. 2002;77(4):761-5.

34.Nguyen $Q$, Kapitz $M$, Downes $K$, Silva $C$. Are early human chorionic gonadotropin levels after methotrexate therapy a predictor of response in ectopic pregnancy? American journal of obstetrics and gynecology. 2010;202(6):630. e1-. e5

35.Skubisz $\mathrm{M}$, Lee J, Wallace $\mathrm{E}$, Tong $\mathrm{S}$. Decline in $\beta$ hCG levels between days 0 and 4 after a single dose of methotrexate for ectopic pregnancy predicts treatment success: a retrospective cohort study. BJOG: An International Journal of Obstetrics \& Gynaecology. 2011;118(13):1665-8.

36.Skubisz $\mathrm{M}$, Dutton $\mathrm{P}$, Duncan WC, Horne AW, Tong $\mathrm{S}$. Using a decline in serum $\mathrm{hCG}$ between days $0-4$ to predict ectopic pregnancy treatment success after single-dose methotrexate: a retrospective cohort study. BMC pregnancy and childbirth. 2013;13(1):30. 